\title{
Comparison of the Effects of Monastrol and Oxomonastrol on Human Hepatoma Cell Line HepG2/C3A
}

\author{
LILIAN AREAL MARQUES ${ }^{1}$, SIMONE CRISTINE SEMPREBON ${ }^{1}$, DANIELE SARTORI ${ }^{1}$, \\ ÂNGELO DE FÁTIMA ${ }^{2}$, LÚCIA REGINA RIBEIRO ${ }^{3}$ and MÁRIO SÉRGIO MANTOVANI ${ }^{1}$ \\ ${ }^{1}$ General Biology Department, State University of Londrina, Londrina, Brazil; \\ ${ }^{2}$ Chemistry Department, Federal University of Minas Gerais, Belo Horizonte, Brazil; \\ ${ }^{3}$ Pathology Department, Júlio de Mesquita Filho State University of São Paulo, Botucatu, Brazil
}

\begin{abstract}
Monastrol and its analog oxomonastrol differ by replacement of the sulfur atom present in monastrol to an oxygen atom in oxomonastrol. Monastrol inhibits the mitotic kinesin family member 11 (EG5), which has been studied for its potential use in cancer therapy. The aim of this study was to investigate the effect of monastrol and oxomonastrol on HepG2/C3A cells. Our results showed that monastrol induced DNA damage, reduced cell proliferation, and upregulated the cytochrome P450 family 1 subfamily A member 1 (CYP1A1) mRNA levels. However, oxomonastrol was cytotoxic only at the highest concentrations used, without reducing cell proliferation and viability. Moreover, no genotoxic damage or alteration of levels of mRNA were found. Our results suggest that monastrol has greater antiproliferative activity compared to oxomonastrol, and this effect is probably related to the DNA damage induced by monastrol and its possible bioactivation demonstrated by the increase in CYPIAI mRNA expression. Moreover, these effects appear to be related to the presence of the sulfur atom in its structure.
\end{abstract}

In recent decades, cancer has become a global health problem and GLOBOCAN statistics indicate that liver cancer is the second most common cause of death from cancer worldwide (1).

The liver performs multiple essential roles to keep the body functioning properly, such as hormone production, synthesis of serum proteins, clearance of toxins, and in host defense and maintenance of metabolic homeostasis, and metabolic detoxification of hormones, cellular waste and

Correspondence to: Lilian Areal Marques, General Biology Department, State University of Londrina, Campus Universitário, P.O. Box 10.011, Londrina, Paraná CEP: 86057-970, Brazil. Tel: +554333714977, e-mail: lilian.areal.marques@gmail.com

Key Words: Monastrol, oxomonastrol, anticancer, CYP1A1, EG5. other xenobiotics (2). Under normal circumstances, detoxification in the liver occurs in two enzymatic steps, termed phase I and phase II reactions, leading to structural alterations which increase the solubility of toxic compounds allowing them to be excreted in the urine and bile. Phase I reactions are carried out by a combination of cytochrome P450 (CYP450) monooxygenases, which perform oxidation, reduction and hydrolysis. If, after this phase, the compounds are sufficiently polar, they can be readily excreted in the urine, without being directed to phase II reactions. Phase II is carried out by transferase enzymes (such as glutathione $S$ transferase (GST), sulphotransferases, $N$-acetyltransferases and UDP-glucuronosyltransferases) involving conjugation with endogenous polar molecules including glucuronic acid, sulphates, and some amino acids, among others. Another important function of phase II enzymes is the detoxification of reactive molecules that may be generated by phase I metabolism of drugs (3).

Monastrol is a synthetic cell-permeable dihydropyrimidine derivative with a low molecular weight that has potential to interfere with mitotic spindle formation and inhibit cell-cycle progression $(4,5)$. This molecule is an allosteric inhibitor of the motor activity of kinesin family member 11 (EG5) through conformational change, preventing the release of ADP from the EG5-ADP complex and maintaining occupation of the catalytic site, thus impeding new ATP hydrolysis (6-8). Without energy to drive the centrosomes toward the poles, the bipolar spindle is not formed and the cell is retained in the $\mathrm{G}_{2} / \mathrm{M}$ phase of the cell cycle and may be directed to apoptosis $(9,10)$. Evidence has shown that this protein is overexpressed in tumor cells compared to nontumor cells (11-13), possibly due to the high mitotic rate observed in neoplastic cells (14).

Some analogs of monastrol have been developed in an attempt to maximize their effect and understand its mechanism of action. One of these analogs is oxomonastrol, in which the sulfur atom replaced by an oxygen atom (15). The aim of this study was to investigated the cytotoxicity, genotoxicity, cell 
A

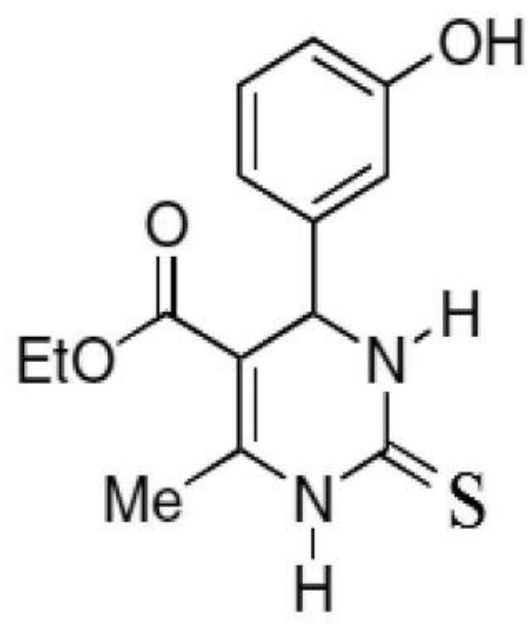

B<smiles>CCOC(=O)C1=C(C)NC(=O)NC1c1cccc(O)c1</smiles>

Figure 1. Chemical structures of the compounds monastrol (A) and oxomonastrol (B) (15).

proliferation kinetics, apoptosis, and the expression of genes involved in cell cycle regulation (adenomatosis polyposis coli $(A P C)$, cyclin A2 (CCNA2), EG5 and tumor protein P53 (TP53)) and metabolism (CYP1A1) in human hepatoma cells, HepG2/C3A, exposed to monastrol and oxomonastrol.

\section{Materials and Methods}

Chemicals. Monastrol and oxomonastrol (Figure 1) were synthesized by Professor Dr. Angelo de Fátima (Federal University of Minas Gerais, Minas Gerais, Brazil) (15). They were dissolved in dimethylsulfoxide (DMSO) (Mallinckrodt Chemicals St. Louis, Missouri, USA) and the concentration of DMSO did not exceed 1\% in culture. Doxorubicin at a concentration of $1 \mu \mathrm{M}$ (Adriblastina ${ }^{\circledR}$, Pharmacia, Milan, Italy) was used as positive control in cytotoxicity, cell proliferation kinetics and comet assay, and camptothecin (Acros Organics, Fisher Scientific Latin America Headquarters, Suwanee, GA, USA) at $150 \mu \mathrm{M}$ was used in the evaluation of apoptosis induction in situ.

Cell line. Human hepatoma cell lines have been widely used as in vitro models for the study of hepatocellular functions, as well as in toxicity studies. The human hepatocellular carcinoma cell line HepG2/C3A (sub-clone of the hepatoma-derived HepG2 cell line) exhibits phenotypic responses including albumin secretion, sensitivity to toxicity, and phase I and phase II metabolizing enzymes. Thus, these cells can bioactivate mutagens and carcinogens $(2,16-18)$. HepG2/C3A was obtained from the Cell Bank of Rio de Janeiro (Rio de Janeiro, Brazil). The cells were cultivated in Dulbecco's modified Eagle's medium (DMEM) supplemented with $10 \%$ fetal bovine serum and antibiotics/ antimycotics (all from Gibco ${ }^{\circledR}$, Life Technologies, Grand Island, $\mathrm{NY}$, USA). The cell cultures were incubated at $37^{\circ} \mathrm{C}, 5 \% \mathrm{CO}_{2}$ and $95 \%$ relative humidity. The cell cycle under these conditions is approximately $24 \mathrm{~h}$.
Cytotoxicity evaluation, 3-(4,5-dimethylthiazol-2-yl)-2,5-diphenyltetrazoliumbromide (MTT)-based assay. The MTT (Invitrogen, Eugene, OR, USA) cytotoxicity assay was performed according to the protocol described by Mosmann (19) with modifications. The cells were seeded at a density of $5 \times 10^{3}$ cells/well in a 96-well microplate. After a $24-\mathrm{h}$ stabilization period, the cells were treated with monastrol and oxomonastrol at concentrations of 1, 10, 100, 200, 300, 400 and $500 \mu \mathrm{M}$ for 24 and $48 \mathrm{~h}$. At the end of this period, the medium was removed and MTT solution $(0.5 \mathrm{mg} / \mathrm{ml})$ added. Subsequently, the cells underwent incubation with MTT for $4 \mathrm{~h}$. Afterwards, the MTT solution was removed and the formazan crystals dissolved in DMSO. The absorbance was measured at $570 \mathrm{~nm}$ using a spectrophotometer (TP Reader - Thermo Plate, China). Cell viability was expressed as a percentage of the negative control. The assay was performed in four replicates and three independent experiments.

Cell proliferation kinetics and viability assay. In a 24-well microplate, $2 \times 10^{4}$ cells/well were seeded with the respective treatments: control; doxorubicin $(1 \mu \mathrm{M})$, monastrol or oxomonastrol $(1,10$ and $100 \mu \mathrm{M})$. After $24,48,72$ and $96 \mathrm{~h}$, the cells were trypsinized (trypsin-EDTA $0.1 \%, 37^{\circ} \mathrm{C}$ ), centrifuged $(5 \mathrm{~min}$ at $84 \times g$ ), resuspended in culture medium and then cells were counted in automated cell counter (Countess $^{\mathrm{TM}}$; Invitrogen). The same cell suspension was used to measure cell viability with $0.4 \%$ Trypan Blue dye (Invitrogen) exclusion method. The assay was performed in triplicate.

Evaluation of apoptosis induction in situ. The morphological detection of apoptosis was performed after staining with the dye Hoechst 33342 (Invitrogen). Cells with chromatin condensation and nuclear fragmentation were considered apoptotic. On coverslips in a 6-well plate, $2 \times 10^{5}$ cells were seeded and incubated for $24 \mathrm{~h}$ for stabilization. Afterwards, the cells were treated with 1,10 and $100 \mu \mathrm{M}$ of monastrol or oxomonastrol and incubated for 24 and $48 \mathrm{~h}$. At the end of each treatment period, coverslips were washed twice with phosphate-buffered saline and then removed from the wells and stained with Hoechst 33342 for $30 \mathrm{~min}$ at $37{ }^{\circ} \mathrm{C}$ in the dark. The 
Table I. Sequence of primers used in quantitative real-time polymerase chain reaction.

\begin{tabular}{|c|c|c|c|}
\hline Gene & Encoded protein & Primer & Reference \\
\hline \multirow[t]{2}{*}{$A P C$} & \multirow[t]{2}{*}{ Adenomatous polyposis coli } & F: 5'AAAGCGCCATGATATTGCACGGTC 3' & \multirow[t]{2}{*}{$(21)$} \\
\hline & & R: 5’TGTTTGCTGTGCTCACGTTTCCAG 3' & \\
\hline \multirow[t]{2}{*}{ CCNA2 } & \multirow[t]{2}{*}{ Cyclin A2 } & F: 5' GACCCTGCATTTGGCTGTG 3' & \multirow[t]{2}{*}{$(22)$} \\
\hline & & R: 5' ACAAACTCTGCTACTTCTGG 3' & \\
\hline \multirow[t]{2}{*}{ CYP1A1 } & \multirow[t]{2}{*}{ Cytochrome P450 family 1 subfamily A member 1} & F- 5’ TCA TCC CTA TTC TTC GCT ACC 3’ & \multirow[t]{2}{*}{ (23) } \\
\hline & & R-5' CAG GAG ATA GCA GTT GTG AC'3' & \\
\hline \multirow[t]{2}{*}{ EG5 } & \multirow[t]{2}{*}{ Kinesin family member 11} & F: $5 `$ CAGGTGGTGGTGAGATGC $3 `$ & \\
\hline & & R: 5' TGGACAAACAACACTTCGGT 3 & (24) \\
\hline \multirow[t]{2}{*}{ TP53 } & \multirow[t]{2}{*}{$\mathrm{p} 53$} & F: 5' TCACACCATCCACTACAACT 3 ' & \multirow[t]{2}{*}{$(25)$} \\
\hline & & R: 5 'GACAGGCACAAACACGCAC 3' & \\
\hline \multirow[t]{2}{*}{ GAPDH } & \multirow[t]{2}{*}{ Glyceraldehyde-3-phosphate dehydrogenase } & F: 5' GAAGGTGAAGGTCGGAGTC 3' & (26) with \\
\hline & & R: 5' GGAAGATGGTGATGGGATTT 3' & modifications \\
\hline
\end{tabular}

analysis was performed using a DM2000 fluorescence microscope (Leica Microsystems, Wetzlar, Hessen, Germany) and 500 cells per treatment were analyzed. The experiment was performed in three independent experiments.

Comet assay. The alkaline comet assay was performed to investigate the genotoxic potential of monastrol and oxomonastrol according to the premises of Tice et al. (20). In culture flasks of $25 \mathrm{~cm}^{2}, 10^{6}$ cells were seeded and incubated for $24 \mathrm{~h}$ stabilization. After the stabilization period, the cells were exposed to 1,10 and $100 \mu \mathrm{M}$ of monastrol or oxomonastrol. After $3 \mathrm{~h}$ of exposure, cells were trypsinized (trypsin-EDTA $0.1 \%, 37^{\circ} \mathrm{C}$ ), the cell suspension was centrifuged $(5 \mathrm{~min}$ at $84 \times \mathrm{g}$ ) and resuspended in $500 \mu \mathrm{l}$ of culture medium. Subsequently, $20 \mu \mathrm{l}$ of cell suspension were mixed with $120 \mu \mathrm{l}$ of low melting point agarose $(0.5 \%)$ and deposited directly on a pre-gelatinized slide with agarose (normal melting point, $1.5 \%$ ) then covered with a coverslip. After solidification of the agarose gel, the coverslip was removed and the slides were placed in a lysis solution $[2.5 \mathrm{M}$ sodium chloride, $100 \mathrm{mM}$ EDTA, $10 \mathrm{mM}$ tris(hydroxymethyl)aminomethane (Tris), $\mathrm{pH} 10 ; 1 \%$ Triton X-100, and 10\% DMSO] for about $1 \mathrm{~h}$ at $4^{\circ} \mathrm{C}$. Afterwards, the slides were placed in alkaline electrophoresis buffer solution (200 mM EDTA, $10 \mathrm{~N}$ sodium hydroxide, and $\mathrm{pH}$ $>13)$ for DNA denaturation before electrophoresis $(25 \mathrm{~V}, 300 \mathrm{~mA}$, $20 \mathrm{~min})$. The slides were then neutralized ( $0.4 \mathrm{M}$ Tris and $\mathrm{pH} 7.5)$ fixed with ethyl alcohol and maintained under refrigeration until analysis. After staining with ethidium bromide, the analysis was conducted visually using fluorescence microscope DM2000 (Leica Microsystems) at $\times 40$ magnification. The determination of damage was classified into four classes based on tail length: Class 0 , representing undamaged cells showing no tail; class 1 , cells with tail size smaller than the diameter of the nucleoid; class 2 , cells with a tail size between 1 and 2 times the diameter of the nucleoid; and class 3, cells with a tail size greater than twice the nucleoid diameter. The Damage Score (DS) was calculated as follows: $\mathrm{DS}=\left(\mathrm{N}_{\text {Class } 1} \times 1\right)+\left(\mathrm{N}_{\text {Class } 2} \times 2\right)+\left(\mathrm{N}_{\text {Class } 3} \times 3\right)$. Cell viability was assessed by Trypan Blue exclusion method, considering only the treatments with rates greater than $80 \%$. The analysis was performed in duplicate and 50 cells per slide were analyzed. The experiments were performed in three independent cycles.
Quantitative real-time polymerase chain reaction $(q R T-P C R)$. For gene expression analysis, cells were seeded at $2 \times 10^{6}$ cell/culture flasks $\left(25 \mathrm{~cm}^{2}\right)$. After $24 \mathrm{~h}$ stabilization, cells were treated with $100 \mu \mathrm{M}$ of monastrol or oxomonastrol for $12 \mathrm{~h}$. Total RNA was extracted using the RNeasy ${ }^{\circledR}$ extraction mini kit (Qiagen, Valencia, CA, USA). Remaining residual amounts of DNA were removed using DNAse I (Invitrogen, Eugene, Oregon, USA) treatment, both according to the manufacturers' instructions. The RNA integrity was verified by $0,8 \%$ agarose gel (28S and $18 \mathrm{~S}$ rRNA pattern of bands), and the concentration and purity by $\mathrm{A}_{260} / \mathrm{A}_{280}$ ratio (BioPhotometer, Eppendorf AG, Hamburg, Germany). Synthesis of cDNA used oligodT primers $(10 \mathrm{pmol} / \mathrm{ml})$ and Moloney Murine Leukemia Virus reverse transcriptase (M-MLV RT) reverse transcriptase (Invitrogen). RTqPCR experiments were performed in a CFX96 TOUCH detection system (Bio-Rad, Singapore) using Platinum ${ }^{\circledR}$ SYBR $^{\circledR}$ Green qPCR SuperMix-UDG kit (Invitrogen) in a total reaction mix volume of 20 $\mu \mathrm{l}\left(2 \mu \mathrm{l}\right.$ cDNA, diluted $1: 5 ; 10 \mu \mathrm{l} \mathrm{SYBR}{ }^{\circledR}$ Green; $0.5 \mu \mathrm{l}$ of $10 \mu \mathrm{M}$ of each gene-specific primer, and $7 \mu \mathrm{l}$ of $\mathrm{H}_{2} \mathrm{O}$ ). The reactions were performed according to the following steps: $3 \mathrm{~min}$ at $95^{\circ} \mathrm{C}$, then 35 cycles of denaturation at $95^{\circ} \mathrm{C}$ for $20 \mathrm{~s}$, annealing at $60^{\circ} \mathrm{C}$ for $30 \mathrm{~s}$ and extension $72^{\circ} \mathrm{C}$ for $20 \mathrm{~s}$ per cycle. Melting curves $\left(50\right.$ to $95^{\circ} \mathrm{C}$ ready every $0.5^{\circ} \mathrm{C}$ ) for each PCR reaction were generated to ensure purity of the amplification product. The data were normalized with glyceraldehyde-3-phosphate dehydrogenase $(G A P D H)$. Experiments were performed in three biological replicates. The primers used are shown in Table I.

Statistical analysis. Data obtained in cytotoxicity, cell proliferation kinetics, apoptosis induction in situ and comet assays were analyzed by analysis of variance (ANOVA) followed by Dunnett's post hoc test $(\alpha=0.05)$, using GraphPad Prism ${ }^{\circledR} 5$ software (San Diego, CA, USA). Real-time qRT-PCR data were analyzed with relative quantification method using $G A P D H$ as a reference gene according to Pfaffl et al. (27) with REST ${ }^{\circ}$ (Relative Expression Software Tool, Munich, Germany) software.

\section{Results}

Effects of monastrol and oxomonastrol in cytotoxicity and cell proliferation. In order to evaluate the effect of monastrol and oxomonastrol on cell proliferation and viability, cells 

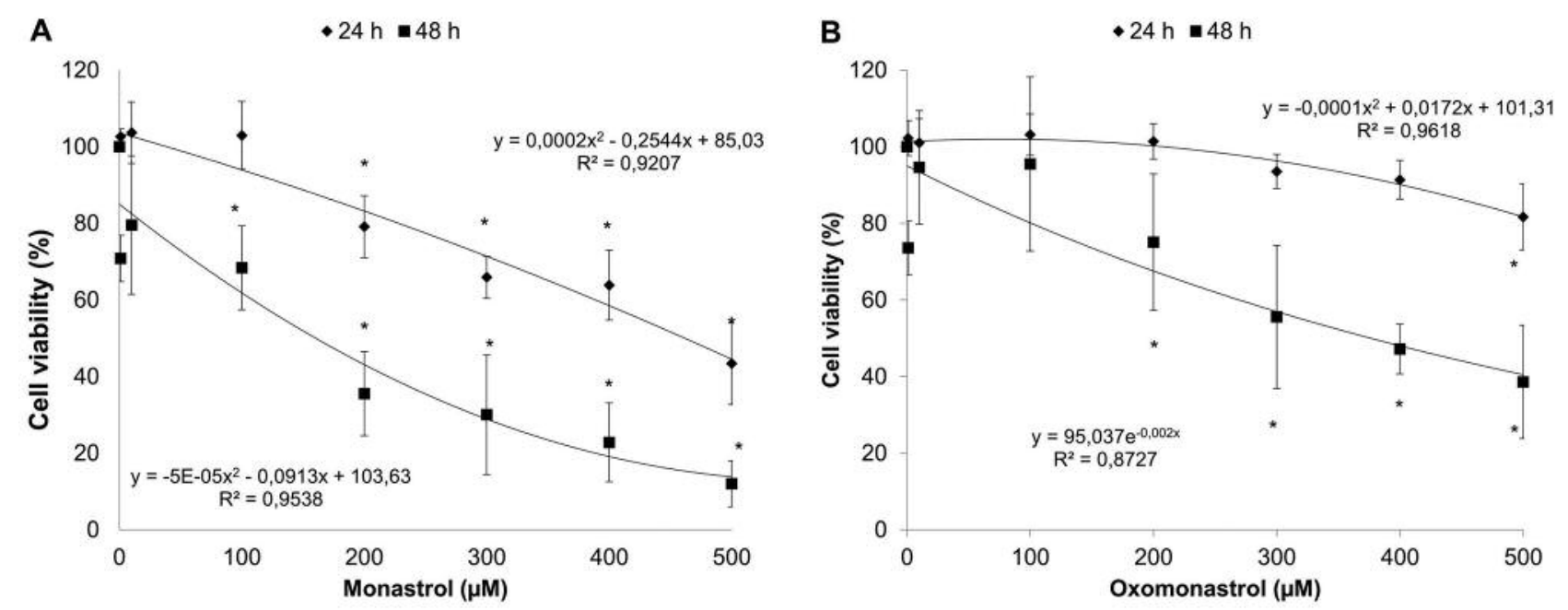

Figure 2. Cell viability curve obtained by 3-(4,5-dimethylthiazol-2-yl)-2,5-diphenyltetrazoliumbromide (MTT)-based assay from the treatment of HepG2/C3A cells with monastrol (A) and oxomonastrol (B) at 1, 10, 100,200, 300, 400 and $500 \mu M$ for 24 h and 48 h. Points represent mean values of cell viability \pm standard deviation obtained from three independent experiments. *Significantly different compared to the control group at $p<0.05$ by ANOVA followed by Dunnett post hoc test.

were exposed to the three lowest concentrations assessed with the MTT assay $(1,10$ and $100 \mu \mathrm{M})$. The MTT assay demonstrated that monastrol reduced cell viability in a dosedependent manner (Figure 2A). Cytotoxicity was significant at a concentration of 200 to $500 \mu \mathrm{M}$ at $24 \mathrm{~h}$, whereas at $48 \mathrm{~h}$, cytotoxicity was already apparent at concentrations of $100 \mu \mathrm{M}$. Concerning oxomonastrol, only the highest concentration $(500 \mu \mathrm{M})$ was cytotoxic at $24 \mathrm{~h}$. However, at $48 \mathrm{~h}$, the concentrations of 200,300 and $400 \mu \mathrm{M}$ also caused significant cytotoxicity (Figure 2B).

The analysis of the cell proliferation curve demonstrated that cells exposed to $100 \mu \mathrm{M}$ of monastrol had a significant reduction in cell proliferation rate compared to the control at 48 to $96 \mathrm{~h}$ of treatment (Figure 3A). With cells exposed to oxomonastrol, there was not a reduction in proliferation nor cell viability (Figure 3C and D) at any of the tested concentrations. The evaluation of cell viability by the Trypan Blue method showed no significant reduction in cell proliferation in the group treated with $100 \mu \mathrm{M}$ of monastrol (Figure 3B).

Effects of monastrol and oxomonastrol on apoptosis. In order to confirm the results of cell viability by Trypan Blue and MTT assay, evaluation of apoptosis induction in situ was performed. Hoechst 33342 staining showed no induction of apoptosis in HepG2/C3A cells treated with monastrol or oxomonastrol for these treatment conditions (Figure 4).

Effects of monastrol and oxomonastrol on DNA damage. In order to investigate the potential for DNA damage induction, a comet assay was performed after $3 \mathrm{~h}$ of treatment with monastrol and oxomonastrol. The mean DS values obtained from the comet assay revealed that monastrol $(100 \mu \mathrm{M})$ significantly induced DNA damage in HepG2/C3A cells when compared to the control (Figure 5). Oxomonastrol at the concentrations tested was not genotoxic.

Effects of monastrol and oxomonastrol on gene expression. The concentration tested in the RT-qPCR assay was $100 \mu \mathrm{M}$ for both compounds. For metabolism-related genes, a significant increase in the mRNA level of CYPlAl gene (more than 6-fold change) was observed after exposure to monastrol (Figure 6). There was no change in mRNA levels of TP53, CCNA2, APC and EG5 genes when exposed to either compound.

\section{Discussion}

New targets for cancer chemotherapy have been widely explored, and compounds that inhibit mitotic kinesins, such as EG5, are becoming highly significant. However, the activities of monastrol and their analogs are not yet entirely understood. In this study, the activities of monastrol and its analog, oxomonastrol, were demonstrated in the human hepatoma cell line, HepG2/C3A. The results demonstrate that monastrol causes cytotoxicity, genotoxicity, reduces cell proliferation and alters the mRNA expression of CYPIAl. In contrast, oxomonastrol was cytotoxic only at higher concentrations.

The evaluation of cytotoxicity showed that monastrol has a greater toxicity compared to oxomonastrol. These results 

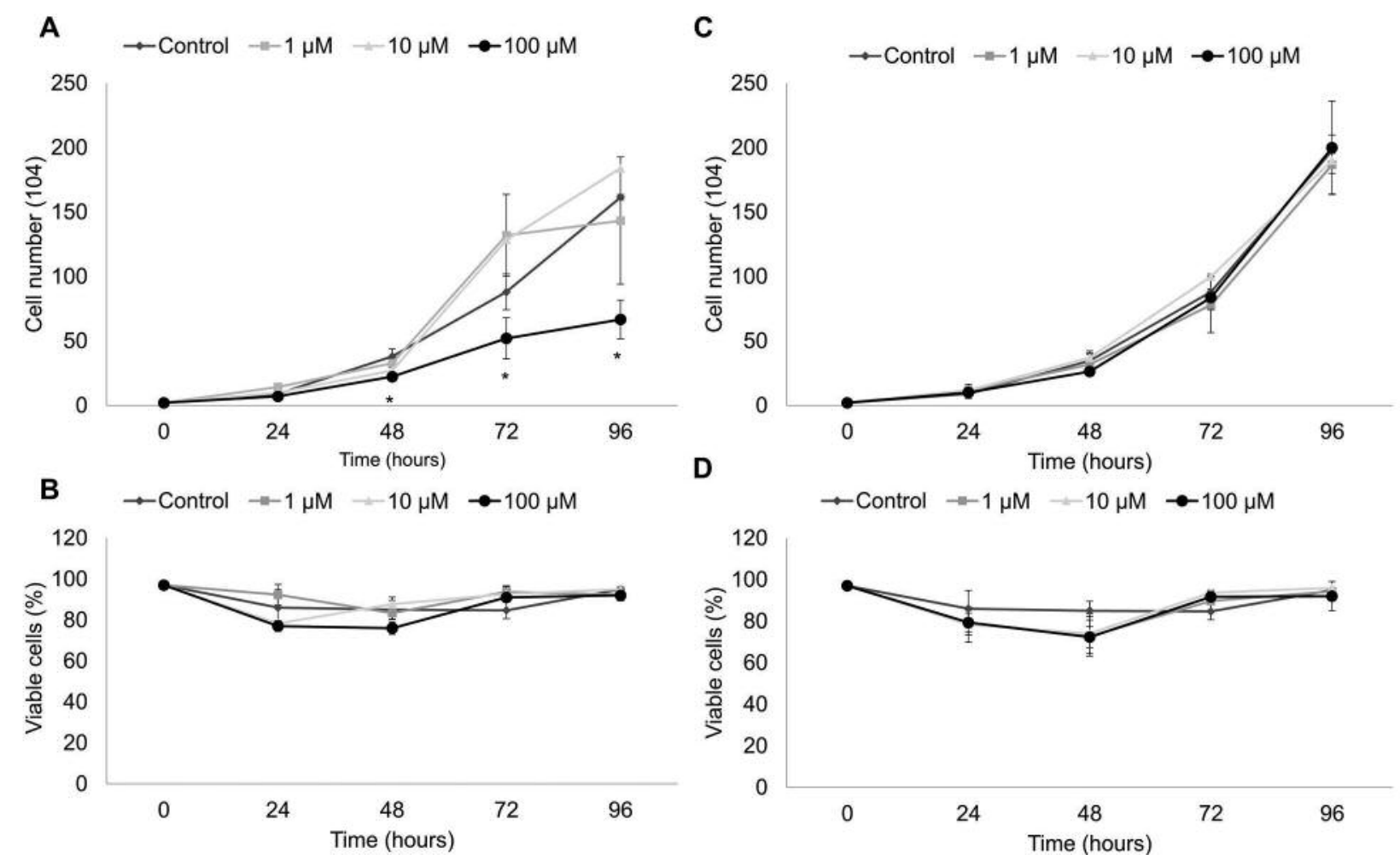

Figure 3. Proliferation kinetics in HepG2/C3A cells. Cell proliferation curve $(A ; D)$ and percentage of viable cells $(B ; C)$ after $24,48,72$ and 96 hours of treatment with monastrol ( $A$ and $B)$ and oxomonastrol $(C$ and $D)$ using automated cell counting (CountessTM; Invitrogen). *Significantly different compared with the control group at $p<0.05$ by ANOVA followed by Dunnett post hoc test.

are consistent with the study conducted by Russowsky et al. (15). These authors observed significant differences in cytotoxicity of both compounds after $48 \mathrm{~h}$ of treatment at a concentration of $85 \mu \mathrm{M}$. While monastrol presented antiproliferative activity against various cell lines (PCO.3, MCF-7, 786-0, UACC.62 and NCI-ADR), its analog was far less efficient. Many studies have reported the ability of monastrol to inhibit cell proliferation through cell arrest in the $\mathrm{G}_{2} / \mathrm{M}$ phase of the cell cycle $(4,6,7,9,28,29)$. In the present study, a significant reduction in proliferation of cells exposed to this compound was observed.

The decrease in cell viability and proliferation may result either from the induction of cell death or inhibition of cell cycle progression after the exposure to monastrol. The data obtained through the analysis of cell viability by the Trypan Blue assay show that despite the reduction in cell proliferation, there was no change in the viability of these cells. Therefore, this indicates that the reduction observed in cell proliferation may be due to a cytostatic effect and not to cell death. In accordance with this, there was no apoptosis induction after exposure of HepG2/C3A to monastrol and oxomonastrol. Shi et al., tested eleven cell lines (OVCAR-5, RPE, HeLa, MDAMB435S, A459, PC3 MCF-7, H460,
U2OS, HCT116 and HT29) and observed that a mitotic arrest occurred around $24 \mathrm{~h}$ after addition of an EG5 inhibitor (30). Nevertheless, the apoptotic response varied among lineages and they noted that there are three types of cells: deathsensitive to apoptosis during mitosis; death-sensitive to apoptosis after mitotic exit; and death-insensitive.

Monastrol is known for its inhibition of mitotic kinesin EG5. However, in this study, there were no alterations in EG5 mRNA levels when cells were exposed to this compound or its analog. Previous studies have obtained similar results, i.e. the EG5 mRNA expression level was not altered when HT-29 and AGS cells were exposed to monastrol (29).

Cells are constantly susceptible to genotoxic stress arising either from metabolic factors or external environment. When genotoxic damage occurs, the cells may be transiently arrested in the cell cycle and DNA repair mechanisms are activated. If the DNA damage is not repairable, apoptosis is activated and eliminates the irreparably damaged cell population (31). The analysis of DNA damage of cells exposed to monastrol and oxomonastrol showed that only monastrol $(100 \mu \mathrm{M})$ was genotoxic. However, DNA damage may have been repaired or not large enough to enable the induction of cell death pathways. 
A

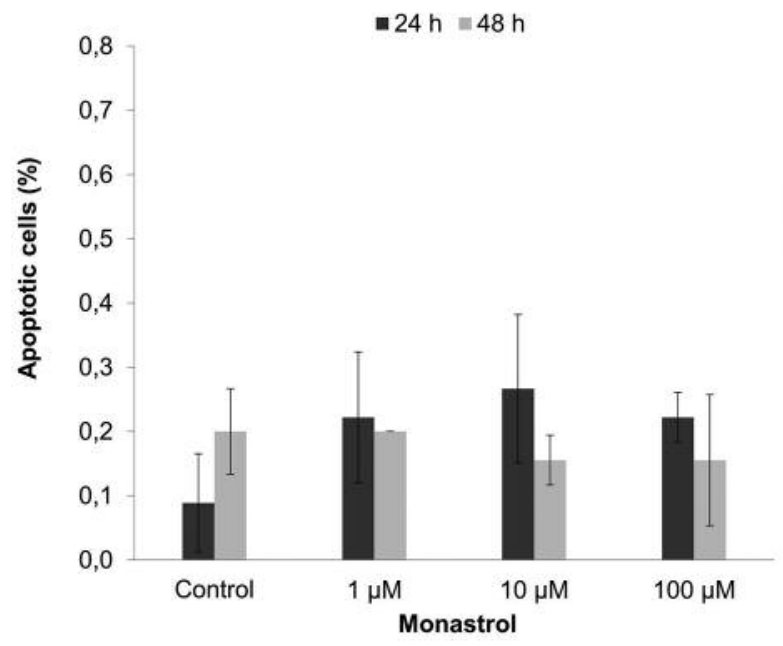

B

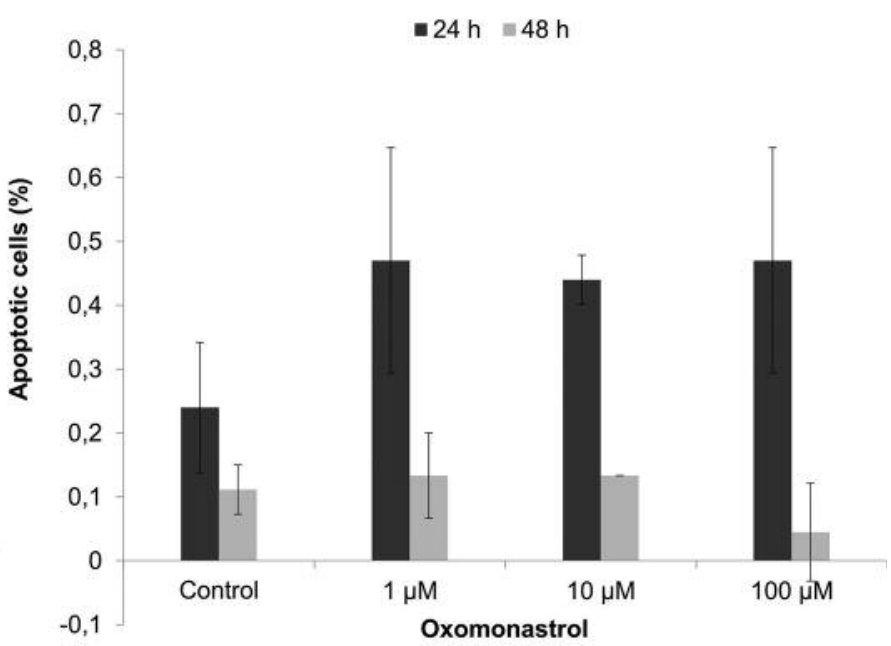

Figure 4. Induction of apoptosis in situ. Apoptotic cells (\%) obtained in situ in HepG2 cells/C3A exposed for 24 and 48 h to monastrol (A) and oxomonastrol $(B)$. The bars represent the mean \pm standard deviation obtained from three independent experiments. There was no statistical difference compared to the control.

In phase I detoxification metabolism, the initial step is the oxygenation of xenobiotics by the CYP450 superfamily. CYP1A1 enzyme is responsible for transforming hydrophobic compounds into more polar metabolites, thereby increasing their excretion. However, this oxygenation often results in bioactivation of xenobiotics, leading to cell toxicity (3). In the present study, an increase of more than 6-fold in the mRNA expression of CYP1A1 gene was found in cells exposed to monastrol compared to the control. However, exposure to oxomonastrol did not reveal alterations in the expression of this gene. This suggests that monastrol may have been bioactivated, resulting in DNA damage and other toxic effects observed in HepG2/C3A cell or the toxicity of this molecule can lead to an increase in CYPlAl cellular response related to its mechanism of detoxification of xenobiotics.

In summary, our results indicate that the presence of the sulfur atom in monastrol is essential for the biological activity of this molecule, given that oxomonastrol had a lesser impact on HepG2/C3A cells. Furthermore, the upregulation of the gene associated with metabolism of xenobiotics $(C Y P 1 A 1)$ together with the antiproliferative response is probably being dictated by genotoxic damage induced by the administration of monastrol.

\section{Acknowledgements}

This research was supported by the National Council of Technological and Scientific Development (CNPq), Coordination for the Improvement of Higher Level (CAPES) and Araucária Foundation, Brazil.

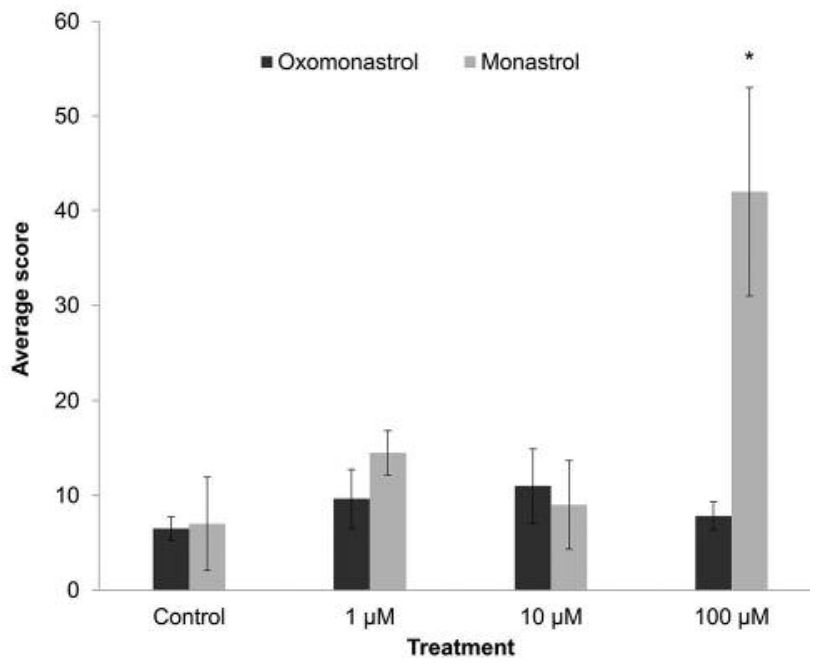

Figure 5. Mean score of comets observed after $3 \mathrm{~h}$ of treatment of HepG2/C3A cells with monastrol and oxomonastrol. The bars represent the mean \pm standard deviation obtained from three independent experiments. *Significantly different compared with the control group at $p<0.05$ by ANOVA followed by Dunnett post-hoc test.

\section{References}

1 Ferlay J, Soerjomataram I, Dikshit R, Eser S, Mathers C, Rebelo M, Parkin DM, Forman D and Bray F: Cancer incidence and mortality worldwide: sources, methods and major patterns in GLOBOCAN 2012. Int J Cancer 136: E359-386, 2015. 


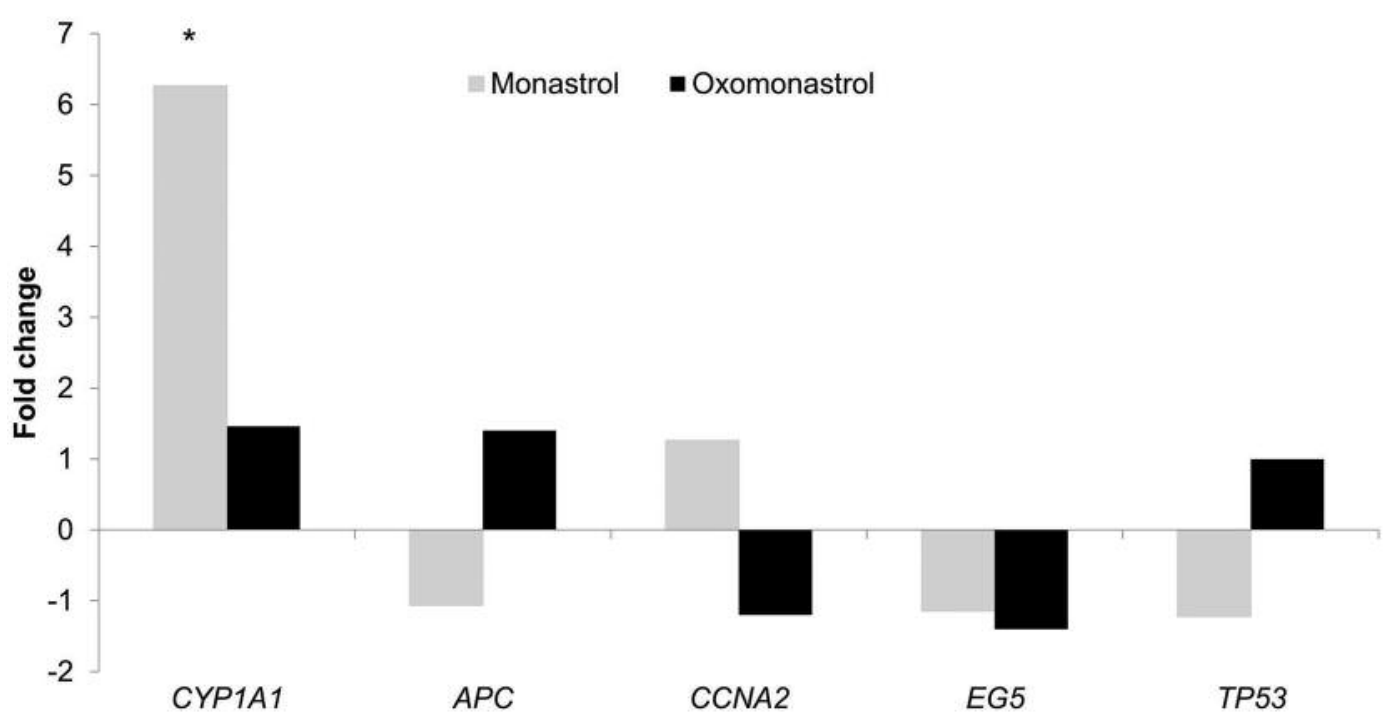

Figure 6. Gene expression. Evaluation of expression of the cytochrome P450 family 1 subfamily A member 1 (CYP1A1), adenomatosis polyposis coli (APC), cyclin A2 (CCNA2), EG5 and tumor protein P53 (TP53) genes by quantitative real-time polymerase chain reaction after 24 h of treatment with $100 \mu \mathrm{M}$ of monastrol and oxomonastrol. *Significantly different compared with the control group at p $<0.05$ by ANOVA followed by Dunnett post hoc test.

2 LeCluyse EL, Witek RP, Andersen ME, and Powers MJ: Organotypic liver culture models: meeting current challenges in toxicity testing. Crit Rev Toxicol 42: 501-548, 2012.

3 Wilkening S, Stahl F and Bader A: Comparison of primary human hepatocytes and hepatoma cell line Hepg2 with regard to their biotransformation properties. Drug Metab Dispos 31: 1035$1042,2003$.

4 Mayer TU, Kapoor TM, Haggarty SJ, King RW, Schreiber SL and Mitchison TJ: Small molecule inhibitor of mitotic spindle bipolarity identified in a phenotype-based screen. Science 286 : 971-974, 1999.

5 Kapoor TM, Mayer TU, Coughlin ML and Mitchison TJ: Probing spindle assembly mechanisms with monastrol, a small molecule inhibitor of the mitotic kinesin, EG5. J Cell Biol 150: 975-988, 2000.

6 Maliga Z, Kapoor TM and Mitchison TJ: Evidence that monastrol is an allosteric inhibitor of the mitotic kinesin EG5 Chem Biol 9: 989-996, 2002.

7 Maliga Z and Mitchison TJ: Small-molecule and mutational analysis of allosteric EG5 inhibition by monastrol. BMC Chem Biol 6: 2, 2006.

8 Cochran JC, Gatial JE, 3rd, Kapoor TM and Gilbert SP: Monastrol inhibition of the mitotic kinesin EG5. J Biol Chem 280: 12658-12667, 2005.

9 Chin GM and Herbst R: Induction of apoptosis by monastrol, an inhibitor of the mitotic kinesin EG5, is independent of the spindle checkpoint. Mol Cancer Ther 5: 2580-2591, 2006.

10 Enos AP and Morris NR: Mutation of a gene that encodes a kinesin-like protein blocks nuclear division in A. nidulans. Cell 60: 1019-1027, 1990.

11 Koller E, Propp S, Zhang H, Zhao C, Xiao X, Chang M, Hirsch SA, Shepard PJ, Koo S, Murphy C, Glazer RI, and Dean NM: Use of a chemically modified antisense oligonucleotide library to identify and validate EG5 (kinesin-like 1) as a target for antineoplastic drug development. Cancer Res 66: 2059-2066, 2006.

12 Le Guellec R, Paris J, Couturier A, Roghi C and Philippe M: Cloning by differential screening of a Xenopus cDNA that encodes a kinesin-related protein. Mol Cell Biol 11: 3395-3398, 1991.

13 Sakowicz R, Finer JT, Beraud C, Crompton A, Lewis E, Fritsch A, Lee Y, Mak J, Moody R, Turincio R, Chabala JC, Gonzales P, Roth S, Weitman S and Wood KW: Antitumor activity of a kinesin inhibitor. Cancer Res 64: 3276-3280, 2004.

14 Carter BZ, Mak DH, Shi Y, Schober WD, Wang RY, Konopleva M, Koller E, Dean NM and Andreeff M: Regulation and targeting of EG5, a mitotic motor protein in blast crisis CML: overcoming imatinib resistance. Cell Cycle 5: 2223-2229, 2006.

15 Russowsky D, Canto RF, Sanches SA, D’Oca MG, de Fatima A, Pilli RA, Kohn LK, Antonio MA and de Carvalho JE: Synthesis and differential antiproliferative activity of Biginelli compounds against cancer cell lines: Monastrol, oxo-monastrol and oxygenated analogues. Bioorg Chem 34: 173-182, 2006.

16 Ebrahimkhani MR, Neiman JA, Raredon MS, Hughes DJ and Griffith LG: Bioreactor technologies to support liver function in vitro. Adv Drug Deliv Rev 69-70: 132-157, 2014.

17 Prot JM, Aninat C, Griscom L, Razan F, Brochot C, Guillouzo CG, Legallais C, Corlu A and Leclerc E: Improvement of HepG2/C3a cell functions in a microfluidic biochip. Biotechnol Bioeng 108: 1704-1715, 2011.

18 Westerink WM and Schoonen WG: Cytochrome P450 enzyme levels in HepG2 cells and cryopreserved primary human hepatocytes and their induction in HepG2 cells. Toxicol In Vitro 21: 1581-1591, 2007.

19 Mosmann T: Rapid colorimetric assay for cellular growth and survival: application to proliferation and cytotoxicity assays. J Immunol Methods 65: 55-63, 1983. 
20 Tice RR, Agurell E, Anderson D, Burlinson B, Hartmann A, Kobayashi H, Miyamae Y, Rojas E, Ryu JC and Sasaki YF: Single cell gel/comet assay: guidelines for in vitro and in vivo genetic toxicology testing. Environ Mol Mutagen 35: 206-221, 2000.

21 Mauro MO, Sartori D, Oliveira RJ, Ishii PL, Mantovani MS and Ribeiro LR: Activity of selenium on cell proliferation, cytotoxicity, and apoptosis and on the expression of CASP9, BCL-XL and APC in intestinal adenocarcinoma cells. Mutat Res 715: 7-12, 2011.

22 Hsieh WT, Huang KY, Lin HY and Chung JG: Physalis angulata induced $\mathrm{G}_{2} / \mathrm{M}$ phase arrest in human breast cancer cells. Food Chem Toxicol 44: 974-983, 2006.

23 Jiao H, Allinson SL, Walsh MJ, Hewitt R, Cole KJ, Phillips DH and Martin FL: Growth kinetics in MCF-7 cells modulate benzo[a]pyrene-induced CYP1A1 up-regulation. Mutagenesis 22: 111-116, 2007.

24 Marques LA, Semprebon SC, Niwa AM, D'Epiro GF, Sartori D, de Fatima A, Ribeiro LR and Mantovani MS: Antiproliferative activity of monastrol in human adenocarcinoma (MCF-7) and non-tumor (HB4a) breast cells. Naunyn Schmiedebergs Arch Pharmacol 389: 1279-1288, 2016.

25 Javelaud D and Besancon F: Inactivation of p21WAF1 sensitizes cells to apoptosis via an increase of both p14ARF and p53 levels and an alteration of the BAX/BCL-2 ratio. J Biol Chem 277: 37949-37954, 2002.

26 Sugaya S, Nakanishi H, Tanzawa H, Sugita K, Kita K and Suzuki N: Down-regulation of SMT3A gene expression in association with DNA synthesis induction after X-ray irradiation in nevoid basal cell carcinoma syndrome (NBCCS) cells. Mutat Res 578: 327-332, 2005.
27 Pfaffl MW, Horgan GW and Dempfle L: Relative expression software tool (REST) for group-wise comparison and statistical analysis of relative expression results in real-time PCR. Nucleic Acids Res 30: e36, 2002.

28 DeBonis S, Simorre JP, Crevel I, Lebeau L, Skoufias DA, Blangy A, Ebel C, Gans P, Cross R, Hackney DD, Wade RH and Kozielski F: Interaction of the mitotic inhibitor monastrol with human kinesin EG5. Biochemistry 42: 338-349, 2003.

29 Leizerman I, Avunie-Masala R, Elkabets M, Fich A and Gheber L: Differential effects of monastrol in two human cell lines. Cell Mol Life Sci 61: 2060-2070, 2004.

30 Shi J, Orth JD and Mitchison T: Cell type variation in responses to antimitotic drugs that target microtubules and kinesin-5. Cancer Res 68: 3269-3276, 2008.

31 Houtgraaf JH, Versmissen J and van der Giessen WJ: A concise review of DNA damage checkpoints and repair in mammalian cells. Cardiovasc Revasc Med 7: 165-172, 2006.
Received January 18, 2017

Revised February 27, 2017

Accepted February 28, 2017 